\title{
Pemanfaatan Limbah Minyak Jelantah Sebagai Upaya Peningkatan Kepedulian Masyarakat Terhadap Lingkungan
}

\author{
Fitri Damayanti*1, Titin Supriyatin ${ }^{2}$ \\ 1,2Program Studi Pendidikan Biologi, FMIPA, Universitas Indraprasta PGRI \\ *e-mail: fitridamayantineng@gmail.com ${ }^{1}$, titinsupriyatin06@gmail.com²
}

\begin{abstract}
Every household produces waste cooking oil that was discharged into the environment without any environmental control. This situation is exacerbated by the lack of public knowledge about the impact of it on health and the environment. Because of that, that was necessary to have an innovation in the use it into products of economic value as solid soap products. This activity was carried out with the PKK Karang Anyar partner, Sawah Besar, Central Jakarta which was conducted by online due to the Covid-19 Pandemic period. This activity was able to encourage the independence economic of partner eco-based. The partners agreed that the training provided could increase the added value of waste cooking oil waste, prevent environmental damage, and increase community entrepreneurship. In addition, it could reduce household expenditure in terms of reducing spending on washing agent related to the economy that was felt heavy when Pandemic Covid-19.
\end{abstract}

Keywords: waste cooking oil, pollution, solid soap

\begin{abstract}
Abstrak
Setiap rumah rumah tangga menghasilkan minyak jelantah. Umumnya minyak jelantah dibuang ke lingkungan tanpa adanya kontrol yang berwawasan lingkungan. Keadaan ini diperparah dengan minimnya pengetahuan masyarakat mengenai dampak minyak jelantah terhadap kesehatan dan lingkungan. Oleh karena itu perlu adanya suatu inovasi pemanfaatan limbah minyak jelantah menjadi produk yang bernilai ekonomi. Inovasi yang diberikan dalam bentuk transfer ilmu pengetahuan kepada masyarakat mengenai pemanfaatan limbah minyak jelantah menjadi produk sabun padat. Kegiatan ini dilakukan dengan mitra PKK Karang Anyar, Sawah Besar, Jakarta Pusat yang dilakukan secara daring pada masa Pandemi Covid-19. Pengabdian ini mampu mendorong kemandirian ekonomi mitra yang berbasis ramah lingkungan. Mitra menilai bahwa pelatihan yang diberikan dapat meningkatkan nilai tambah limbah minyak jelantah, mencegah kerusakan lingkungan, dan meningkatkan wirausaha masyarakat. Selain itu, dapat mengurangi belanja rumah tangga dalam hal mengurangi belanja bahan pencuci peralatan dapur terkait perekonomian yang dirasa berat saat Pandemi Covid-19.
\end{abstract}

Kata kunci: minyakjelantah, pencemaran, sabun padat

\section{PENDAHULUAN}

Masyarakat Indonesia pada umumnya lebih menyukai makanan yang digoreng. Hal ini menyebabkan konsumsi minyak goreng sawit setiap tahun terus meningkat seiring dengan peningkatan jumlah penduduk. Berdasarkan data BPS (2019), konsumsi minyak goreng sawit pada tahun 2018 mencapai 10,79 liter/kapita/tahun. Konsumi minyak goreng sawit tahun 2019 dan 2020 diprediksi mengalami peningkatan masing-masing sebesar 11,09 dan 11,38 liter/kapita/tahun.

Perekonomian pada tingkat rumah tangga sangat beragam, sehingga dalam penggunaan minyak goreng ada yang menggunakan untuk satu kali pemakaian namun ada yang menggunakan sampai beberapa kali pemakaian. Pada dasarnya minyak goreng dapat digunakan maksimal untuk 3 atau 4 kali penggorengan. Jika minyak goreng ini digunakan berkali-kali, maka kandungan asam lemak semakin jenuh dan minyak akan berubah warna yang disebut minyak jelantah. Minyak jelantah ini sangat tidak baik untuk dikomsumsi atau digunakan kembali untuk menggoreng makanan (Lipoeto, 2011). Bila minyak goreng jelantah ini terus menerus masuk ke dalam tubuh manusia dan terjadi akumulasi maka akan menimbulkan penyakit walaupun pengaruhnya baru akan terlihat pada jangka panjang. Dampak buruk bagi tubuh akibat mengkonsumsi minyak 
jelantah antara lain terjadi deposit lemak yang tidak normal, kanker, dan kehilangan fungsi kontrol pada pusat syaraf.

Minyak jelantah selain menimbulkan masalah bagi kesehatan manusia juga menimbulkan masalah lingkungan. Umumnya minyak jelantah dibuang ke lingkungan tanpa adanya kontrol yang berwawasan lingkungan. Hal ini menimbulkan dampak negatif bagi lingkungan yaitu menimbulkan masalah pencemaran air maupun tanah. Minyak jelantah yang terserap dalam tanah dapat mencemari tanah dan berakibat menurunnya tingkat kesuburan tanah serta terbukti mempengaruhi kandungan mineral dalam air bersih. Keadaan ini diperparah dengan minimnya pengetahuan masyarakat mengenai dampak minyak jelantah terhadap lingkungan.

Limbah minyak jelantah adalah permasalahan yang dihadapi sektor kuliner mulai dari restoran besar sampai kaki lima begitu juga pada tingkat rumah tangga. Pada umumnya pengolahan makanan disajikan dengan cara digoreng sehingga dapat dipastikan setiap rumah tangga menghasilkan limbah minyak jelantah. Selama ini mitra pengabdian kepada masyarakat yaitu PKK Karang Anyar, Sawah Besar membuang begitu saja limbah minyak jelantah di saluran pembuangan air atau di tanah. Limbah minyak jelantah tersebut selama ini belum pernah diolah mitra menjadi sesuatu yang bernilai ekonomi. Hal ini terjadi karena keterbatasan mitra dalam hal pengetahuan mengenai limbah minyak jelantah, yaitu: bahaya minyak jelantah terhadap kesehatan, pengolahan limbah minyak jelantah yang tidak membahayakan lingkungan, dan potensi ekonomis yang dimiliki minyak jelantah. Oleh karena itu perlu adanya suatu inovasi untuk mengolah limbah minyak goreng menjadi suatu produk yang bernilai ekonomi.

Pemanfaatan limbah terbukti mampu menciptakan ekonomi kreatif masyarakat yang ramah lingkungan, seperti pemanfaatan limbah batang pisang (Syarifuddin \& Hamzah, 2019), limbah sampah organik dan anorganik (Suryani $d k k ., 2019)$ dan limbah kulit pisang (Ernawati \& Aryani, 2019). Hal yang sama dapat dilakukan pada limbah minyak jelantah sebagai bahan baku untuk berbagai macam produk yang bernilai ekonomi. Kusumaningtyas $d k k$. (2018); Erviana $d k k$. (2018); Rozaq \& Laksanawati (2018); Haqq (2019), menggunakan limbah minyak jelantah sebagai bahan paku untuk pembuatan sabun. Lipoeto (2011); Adhari dkk. (2016); Erna dan Wiwit (2017); Syam dkk. (2018); Harahap \& Yulia (2018) mengubah minyak jelantah menjadi bahan bakar minyak tanah atau biofuel. Selain itu, pemanfaatan limbah minyak jelantah digunakan untuk fotokatalis carbon nanodots sebagai penjernih air limbah batik (Priyanto $d k k$., 2017).

Salah satu solusi yang ditawarkan untuk mengatasi permasalahan mitra adalah melakukan pemanfaatan limbah minyak jelantah menjadi sabun padat sehingga minyak jelantah bernilai eknomi dan tidak mencemari lingkungan. Tujuan dari kegiatan pengabdian kepada masyarat ini adalah untuk memberikan wawasan dan pelatihan kepada mitra terkait dengan pemanfaatan limbah minyak jelantah menjadi bahan baku sabun padat.

Kegiatan pengabdian kepada masyarakat ini diharapkan memberikan kontribusi dalam hal meningkatkan nilai ekonomi minyak jelantah dan mampu membangkitkan kesadaran masyarat akan kesehatan serta menjaga lingkungan. Upaya ini berkaitan dengan usaha pemerintah untuk meningkatkan kesehatan masyarakat dan kesadaran lingkungan. Pelatihan yang diberikan diharapkan setiap rumah tangga mitra dapat secara mandiri membuat sabun padat untuk keperluan rumah tangga tanpa harus membeli sehingga dapat mengurangi pengeluaran belanja rumah tangga.

\section{METODE}

Pengabdian kepada masyarakat telah dilaksanakan pada April-Juli 2020 dengan mitra kelompok PKK Karang Anyar RT 014/RW 001, Sawah besar, Jakarta Pusat. Pelaksanaan pengabdian ini dilakukan secara daring karena masa Pandemik Covid-19 dan mengikuti anjuran pemerintah untuk social distancing. Selain itu adanya peraturan PSBB (Pembatasan Sosial Berskala Besar) sehingga tidak dapat dilakukan secara langsung. Kegiatan ini terdiri dari beberapa tahapan, yaitu: 1) survei dan diskusi, 2) ketrampilan, dan 3) evaluasi. 
Survei dan diskusi dilakukan untuk memastikan agar pelaksanaan pengabdian ini dapat berjalan dengan lancar dan sesuai dengan jadwal mitra. Tahap ini bertujuan untuk menentukan kebutuhan yang tepat bagi mitra dalam menghadapi permasalahan mitra. Hasil yang diperoleh adalah data jumlah peserta, waktu pelaksanaan, dan platform yang digunakan untuk pelatihan secara daring. Peningkatan ketrampilan mitra dalam mengolah limbah minyak jelantah dilakukan dalam bentuk pelatihan. Tahap ini diutamakan memberi pengetahuan mengenai: (1) potensi ekonomis limbah minyak jelantah menjadi produk sabun padat dan (2) implementasi iptek pemanfaatan limbah minyak jelantah.

Kegiatan pelatihan pembuatan sabun padat berbahan limbah minyak jelantah dilakukan dalam dua tahap, yaitu: pembuatan sabun padat dan pembuatan kemasan sabun padat. Pembuatan sabun padat berbahan limbah minyak jelantah memerlukan bahan-bahan seperti: minyak jelantah, soda api, air, dan bibit parfum aroma lemon. Sedangkan peralatan yang dibutuhkan, yaitu: gelas ukur, pengaduk steinless, wadah plastik, dan cetakan sabun dengan memanfaatkan botol plastik bekas. Proses pembuatan sabun padat cuci piring berdasarkan modifikasi dari Erviana dkk. (2018); Haqq (2019). Soda api sebanyak 16 g dan $27 \mathrm{ml}$ air dimasukan dalam wadah kemudian diaduk perlahan. Selama proses pengadukan, minyak jelantah dimasukkan sebanyak $100 \mathrm{ml}$. Pengadukan dilakukan hingga larutan mengental. Bibit parfum dapat ditambahkan dalam larutan untuk memberikan aroma yang wangi. Larutan yang telah mengental dituang ke dalam cetakan dari botol plastik bekas dan didiamkan pada suhu ruang. Sabun yang dihasilkan tidak dapat langsung digunakan tetapi harus didiamkan kurang lebih selama dua minggu. Proses pendiaman ini bertujuan untuk menghilangkan aktivitas soda api dan menghilangkan bau dari minyak jelantah.

Sabun padat yang telah dihasilkan dapat dibungkus dengan menggunakan bahan yang tersedia di rumah tanpa harus membeli. Pembuatan wadah ini bertujuan agar sabun yang telah dibuat dapat diberikan ke teman, handau taulan atau sebagai souvenier. Alat dan bahan yang digunakan sangat sederhana yaitu: kertas coklat, pita, lem kertas, penggaris, pensil, dan pembolong kertas.

Setelah pelaksanaan pelatihan maka dilakukan evaluasi dengan mitra untuk menilai ketepatan sasaran pada pelatihan dan pelaksanaan pengabdian secara keseluruhan. Pelaksanaan evaluasi ini dilakukan untuk mengetahui pengetahuan mitra sebelum dan setelah pelatihan diberikan. Evaluasi dilaksanakan dengan mengisi kuesioner menggunakan google form.

\section{HASIL DAN PEMBAHASAN}

Pengabdian kepada masyarakat dilakukan dengan mitra Ibu-Ibu yang bergabung dalam kelompok PKK Karang Anyar RT 014/RW 001, Kelurahan Karang Anyar, Sawah Besar, Jakarta Pusat yang terdiri dari 20 orang. Mitra pengabdian terdiri dari beragam usia mulai dari rentang usia 15-75 yang didominasi usia antara 36-45 tahun (Gambar 1A). Latar belakang pendidikan akhir mitra juga beragam mulai dari tingkat Sekolah Dasar sampai Strata 1 (Gambar 1B).

A

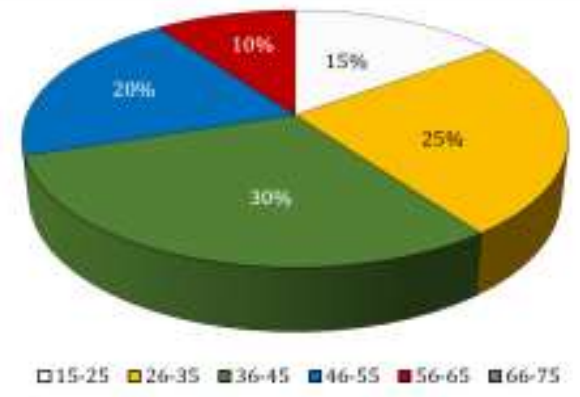

B

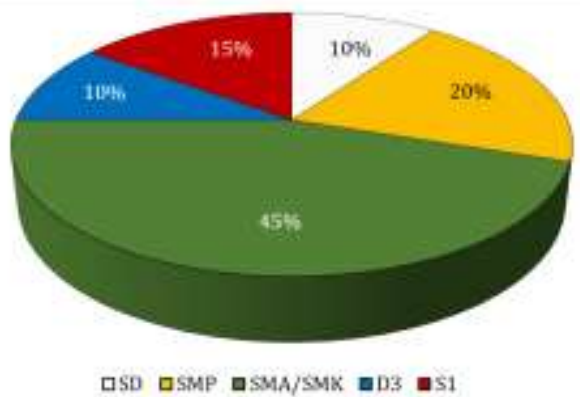

Gambar 1. Data mitra pengabdian pembuatan sabun padat berbahan dasar minyak jelantah. Rentang usia mitra (A); Tingkat pendidikan akhir mitra (B) 
Kegiatan ini dimulai dari kegiatan survei yang bertujuan untuk menentukan solusi yang tepat untuk mengatasi permasalahan mitra, waktu pelaksanaan, dan platform yang digunakan dalam pelatihan secara daring. Hasil survei telah disepakati waktu pelatihan dibagi dalam dua waktu pelaksanaan. Platform yang digunakan untuk pelatihan daring adalah WhatsApp Group (WAG) dan video yang diunggah ke YouTube. Pemilihan WAG sebagai salah satu plaftform daring dengan pertimbangan bahwa semua mitra memiliki WA dan tidak membutuhkan banyak quota internet. Keputuskan ini juga didasari hasil survei yang diberikan dalam bentuk google form. Hasil survei memperlihatkan dari 20 orang mitra 17 memilih melalui WAG dan hanya dua yang mampu atau terbiasa mengooperasikan Zoom Cloud Meeting (Gambar 2). Berdasarkan hal tersebut maka penggunaan platform pelatihan menggunakan video conference seperti Zoom Cloud Meeting tidak dilakukan. Selain itu, penggunaan video conference menghabiskan banyak quota internet dan tidak semua mitra terbiasa menggunakan video conference. Pelatihan yang diberikan dibuat dalam bentuk video yang diunggah ke YouTube sehingga mitra dapat mengaksesnya kapanpun dan dimanapun.

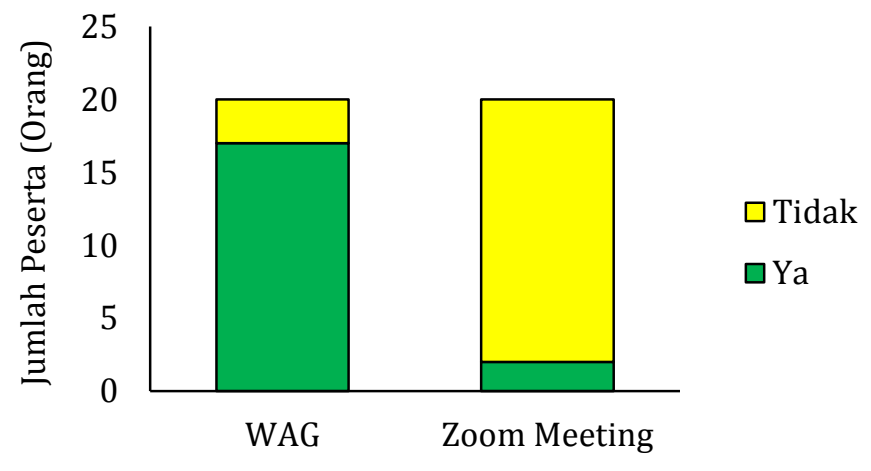

Gambar 2. Hasil survei untuk penentuan platform pelatihan secara daring. Data pemilihan WAG sebagai platform pelatihan secara daring (kiri) dan data kemampuan mitra mengoperasikan Zoom Cloud Meeting

Pengetahuan dan kesadaran mitra mengenai bahaya dan pemanfaatan limbah minyak jelantah masih sangat sedikit sekali. Oleh karena itu pelatihan pembuatan sabun padat berbahan limbah minyak jelantah ini penting dilakukan mengingat limbah ini merupakan salah satu produk limbah yang pasti dihasilkan pada setiap tingkat rumah tangga. Hasil survei menunjukkan bahwa $100 \%$ mitra pengabdian menyukai gorengan dan selalu memasak dengan cara digoreng. Diperkirakan rata-rata masing-masing keluarga dari mitra sebanyak 20 orang menghabiskan minyak goreng sebanyak 56 liter/minggu, maka kebutuhan untuk satu bulan sebanyak 224 liter/bulan (Gambar 3A). Pengetahuan penggunaan minyak goreng berulang maksimal 3 sampai 4 kali penggorengan pun masih sangat rendah. Beberapa mitra bahkan menggunakan minyak goreng secara berulang lebih dari 4 kali sebanyak 11 dari 20 orang mitra. Namun ada pula yang hanya menggunakan minyak goreng berulang kurang dari 2 kali (Gambar 3B).
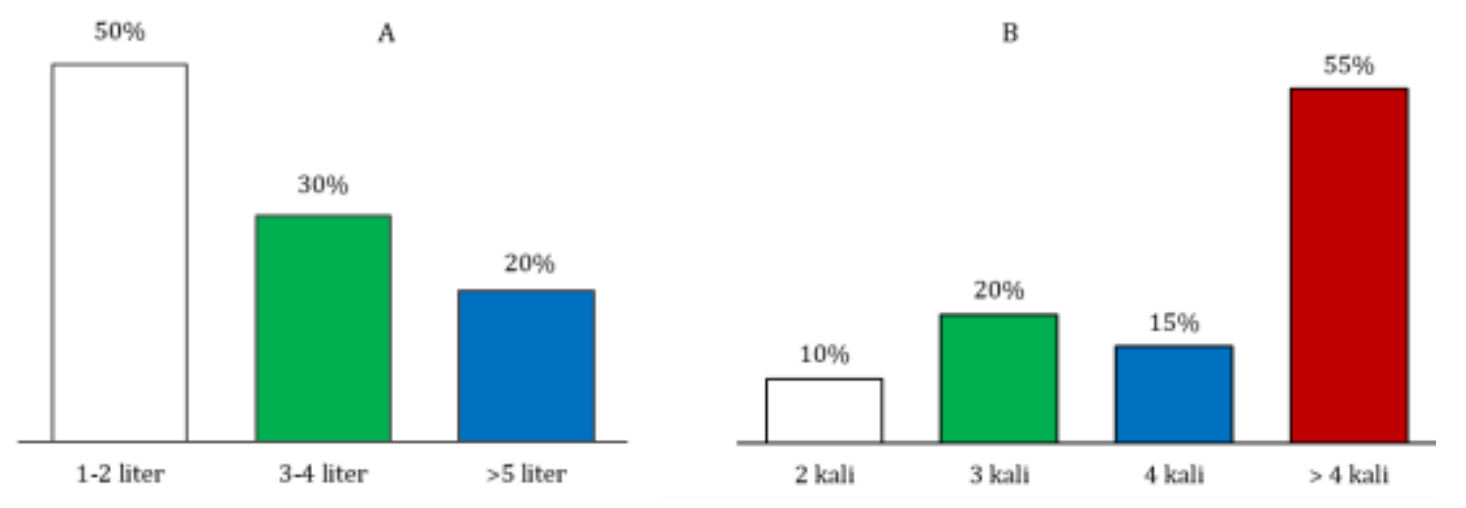

Gambar 3. Kebutuhan minyak goreng mitra pengabdian/minggu (A); Jumlah pengulangan penggunaan minyak goreng (B) 
Hasil kegiatan memasak setiap rumah tangga akan menghasilkan limbah minyak jelantah dalam jumlah besar. Selama ini mitra pengabdian umumnya membuang limbah minyak jelantah ke tempat pembuangan atau saluran air tanpa adanya pengolahan atau pemanfaatan sehingga dapat mencemari lingkungan. Data kuesioner memperlihatkan hanya 3 dari 20 mitra pengabdian yang memanfaatkan atau mendaur ulang limbah minyak jelantah (Gambar 4).

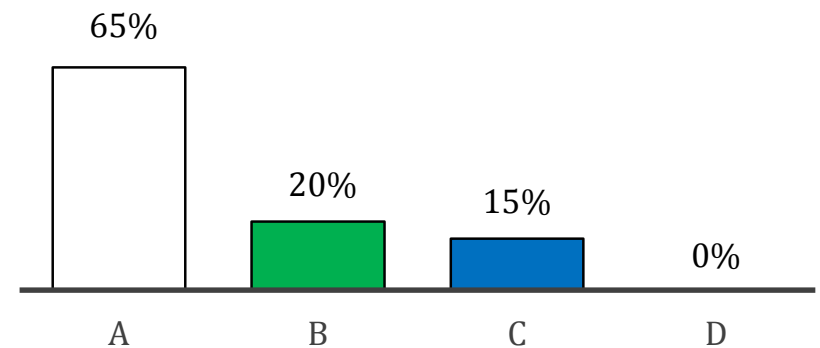

Gambar 4. Data pembuangan limbah minyak jelantah mitra pengabdian. Saluran pembuangan air (A); Tanah (B); Disimpan untuk dimanfaatkan/didaur ulang (C); dan Dijual (D)

Penyuluhan dan pelatihan mengenai bahaya dan pemanfaatan limbah minyak jelantah merupakan salah satu upaya meningkatkan kesadaran masyarakat terhadap lingkungan. Limbah minyak jelantah salah satunya dapat dimanfaatkan untuk pembuatan sabun padat yang murah dan mudah dilakukan. Sabun padat yang dihasilkan dapat digunakan untuk mencuci peralatan rumah tangga namun tidak disarankan untuk membersihkan badan. Melalui kegiatan pelatihan ini diharapkan dapat mengembangkan kemandirian ekonomi mitra melalui pembuatan sabun padat secara mandiri pada tingkat rumah tangga yang berbasis ramah lingkungan melalui pemanfaatan limbah minyak jelantah. Kemandirian ekonomi mitra dapat dicapai dengan mengurangi biaya belanja pada tingkat rumah tangga terutama pembelian sabun cuci piring bahkan dapat menjadi wirausaha rumah tangga.

Pelatihan pembuatan sabun padat diberikan melalui WAG dan video yang diunggah ke YouTube. Pelatihan dibuat dalam dua video. Video pertama adalah proses pembuatan sabun padat dengan link https://youtu.be/rDImwhzx8Gk. Video kedua adalah pembuatan kemasan sabun dengan link https://youtu.be/_4cwDGd26RA. Gambar 5 memperlihatkan proses pembuatan sabun berbahan dasar limbah minyak jelantah.

Mitra pengabdian memperlihatkan antusias yang tinggi. Hal ini terlihat dari respon positif yang diberikan para mitra melalui pertanyaan dan tanggapan di WAG yang berhubungan dengan materi pelatihan yang diberikan. Beberapa mitra bahkan telah mempraktekkannya di rumah dan memberikan testimoni yang positif akan manfaat sabun padat dari limbah minyak jelantah. Kegiatan pelatihan berjalan sesuai dengan agenda yang telah disepakati dan berjalan lancar walaupun secara daring.

Keberhasilan capaian kegiatan pengadian ini diukur berdasarkan hasil kuesioner yang diisi oleh seluruh mitra. Kuesioner diberikan dalam bentuk google form di WAG. Pemberian kuesioner bertujuan untuk mengetahui pemahaman pengetahuan yang diberikan seputar bahaya limbah minyak jelantah dan praktek pembuatan sabun padat berbahan dasar limbah minyak jelantah. Pertanyaan pada kuesioner terdiri dari beberapa pertanyaan yang berkaitan dengan pengetahuan mitra mengenai pemanfaatan limbah minyak jelantah. 


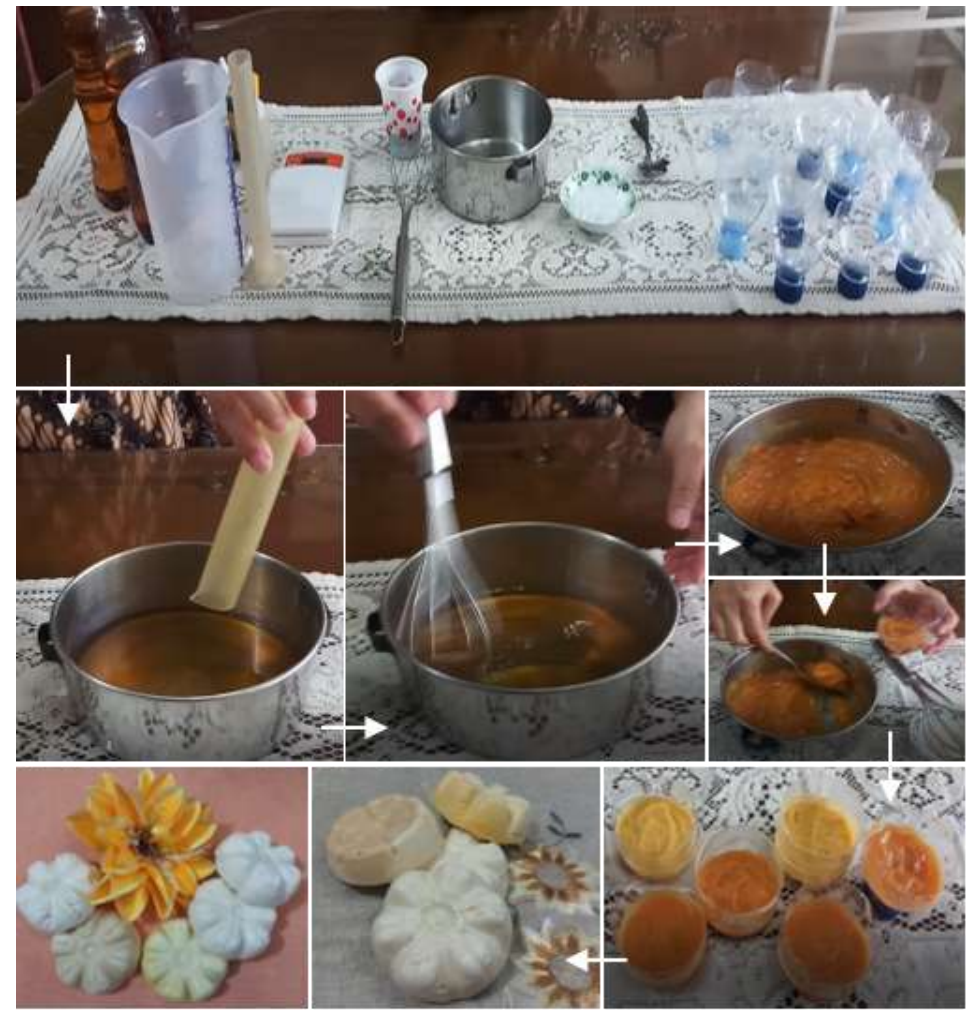

A

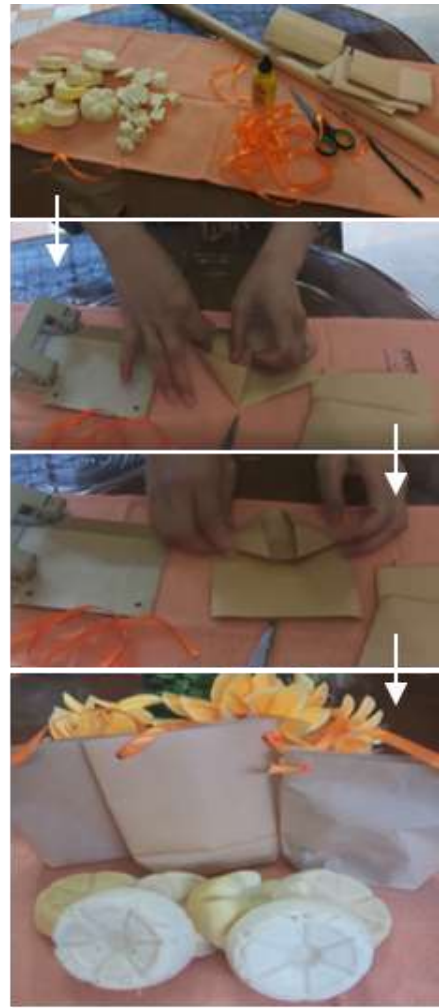

B

Gambar 5. Proses pembuatan sabun padat berbahan limbah minyak jelantah (A); Pembuatan kemasan sabun padat minyak jelantah menggunakan bahan sederhana yang tersedia di rumah tanpa harus membeli (B)

Berdasarkan data kuesioner yang diberikan hanya beberapa mitra yang mengetahui pemanfaatan limbah minyak jelantah menjadi sabun padat. Pengetahuan mitra seputar pemanfaatan limbah minyak jelantah menjadi sabun padat hanya sebesar 20\% (Gambar 6A). Hasil kuesioner juga memperlihatkan hanya $15 \%$ mitra yang telah membuat sabun padat dengan memanfaatkan limbah minyak jelantah (Gambar 6B). Kegiatan ini selain meningkatkan pengetahuan mitra mengenai pemanfaatan minyak jelantah, juga terbukti berhasil meningkatkan minat mitra dalam memanfaatkan limbah minyak jelantah menjadi sabun padat.

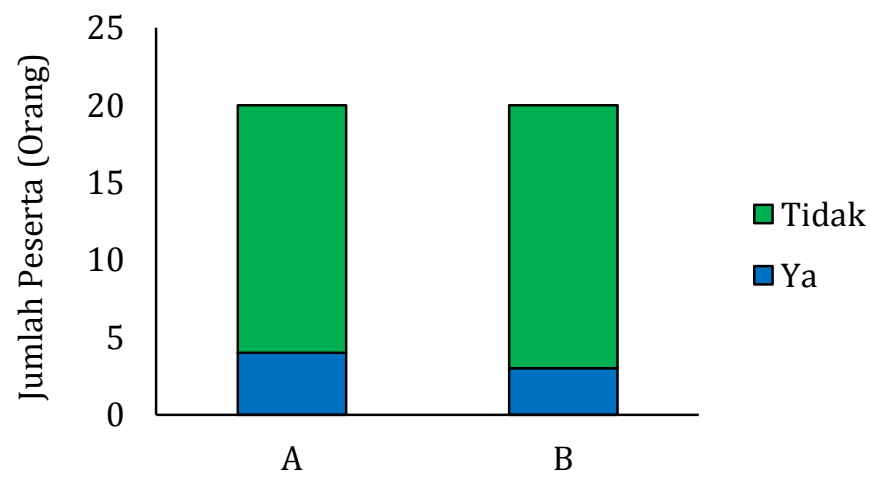

Gambar 6. Data mitra mengenai pengetahuan pemanfaatan limbah minyak jelantah menjadi sabun padat

(A); Data mitra yang telah memanfaatkan minyak jelantah menjadi sabun padat sebelum pelatihan (B)

Hasil kuesinoner juga menunjukkan bahwa hampir semua mitra memiliki kesepemahaman bahwa apa yang telah dijelaskan dan dipraktekan penerapannya sangat mudah 
di rumah masing-masing. Selain itu dapat memanfaatkan bahan-bahan yang tersedia di lingkungan tempat tinggal mitra tanpa harus membeli. Seluruh mitra pengabdian sepakat bahwa pelatihan yang diberikan mampu mengurangi limbah minyak jelantah melalui pembuatan sabun dari minyak jelantah. Mitra pengabdian memberikan respon yang positif bahwa pembuatan sabun dari minyak jelantah merupakan salah satu terobosan atau inovasi yang ramah lingkungan (Gambar 7).

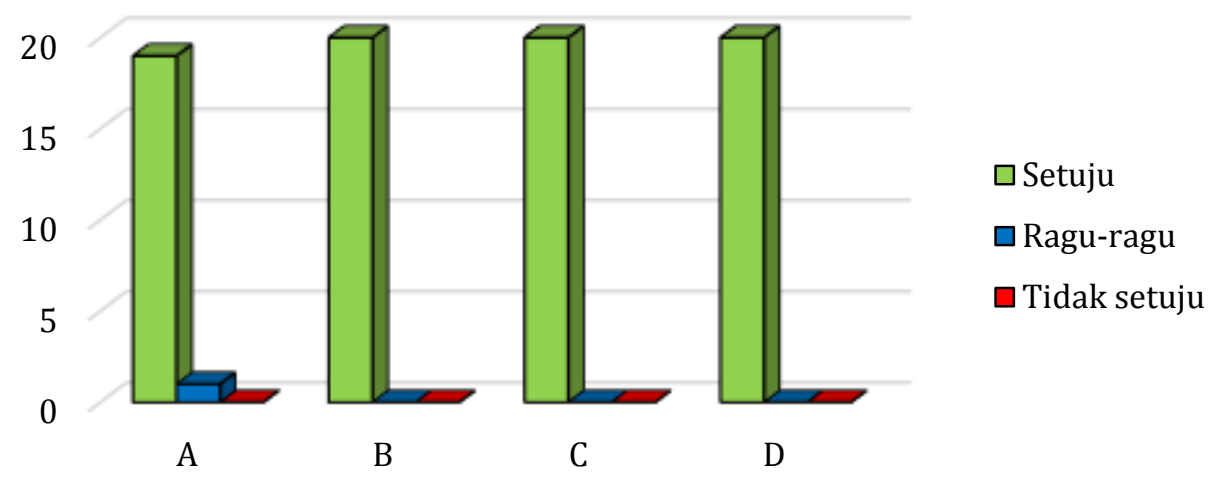

Gambar 7. Respon mitra mengenai kemudahan penerapan pembuatan sabun padat berbahan minyak jelantah di rumah (A); Respon mitra mengenai kemudahan memperoleh bahan yang digunakan untuk pembuatan sabun padat berbahan minyak jelantah (B); Pandangan mitra mengenai kebermanfatan pembuatan sabun dari minyak jelantah dapat mengurangi limbah minyak jelantah di lingkungan tempat tinggal mitra (C); Respon mitra bahwa pembuatan sabun dari minyak jelantah merupakan terobosan atau inovasi yang ramah lingkungan

Kegiatan pengabdian yang telah dilakukan diharapkan mampu mengatasi masalah limbah minyak jelantah khususnya pada tingkat rumah tangga. Mitra pengabdian sepakat bahwa sabun padat dari minyak jelantah yang dihasilkan mampu membersihkan peralatan dapur dengan baik bahkan mampu menghilangkan noda minyak (Gambar 8A). Selain itu, sabun padat yang dihasilkan ternyata mampu membersihkan lap dapur yang sulit dibersihkan dengan detergen. Mitra pun sepakat bahwa pemanfaatan limbah minyak jelantah dapat meningkatkan kemandirian ekonomi melalui penyediaan sabun cuci piring secara mandiri tanpa harus membeli. Hal ini terkait dengan perekonomian yang dirasa berat saat Pandemi Covid-19. Hal ini terlihat dari jawaban kueisioner, 19 dari 20 mitra memberikan jawaban setuju apabila hasil pembuatan sabun padat berbahan limbah minyak jelantah mampu mengurangi biaya belanja rumah tangga terutama belanja bahan pencuci peralatan dapur (Gambar 8B).

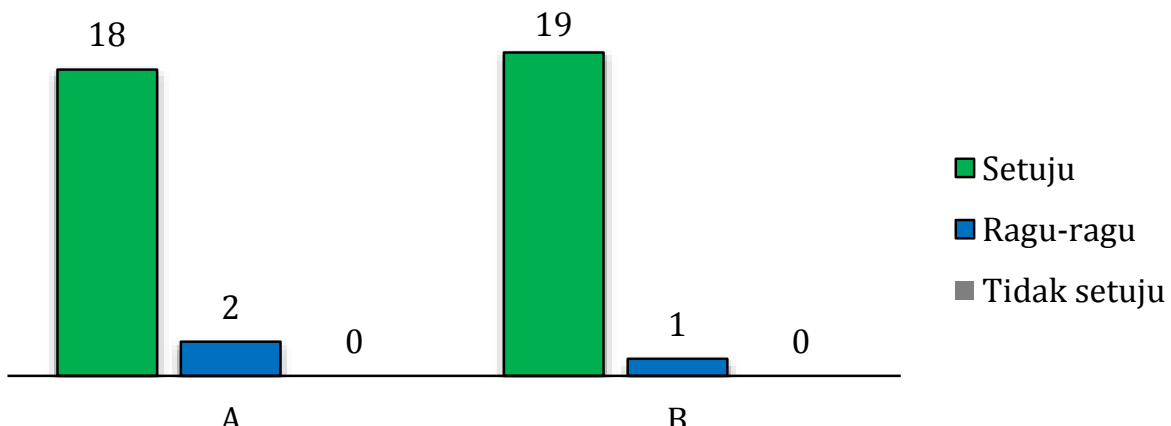

Gambar 8. Respon mitra mengenai sabun padat dari minyak jelantah mampu membersihkan dan menghilangkan noda minyak pada peralatan makan (A); Respon mitra mengenai pemanfaatan sabun dari limbah minyak jelantah dapat mengurangi biaya belanja terutama belanja bahan pencuci peralatan dapur 


\section{KESIMPULAN}

Pelatihan pembuatan sabun padat berbahan dasar limbah minyak jelantah adalah salah satu upaya meningkatkan kepedulian masyarakat terhadap lingkungan. Kegiatan yang telah dilakukan dan diterapkan bersama mitra ibu-ibu PKK Karang Anyar, sawah Besar, Jakarta Pusat terbukti mampu meningkatkan minat dan pengetahuan mitra mengenai pemanfaatan limbah minyak jelantah menjadi sesuatu yang bernilai ekonomi. Pengabdian ini juga mampu mendorong kemandirian ekonomi mitra yang berbasis ramah lingkungan. Mitra menilai bahwa pelatihan yang diberikan dapat meningkatkan nilai tambah limbah minyak jelantah, mencegah kerusakan lingkungan, dan meningkatkan wirausaha masyarakat. Selain itu, dapat mengurangi belanja rumah tangga dalam hal mengurangi belanja bahan pencuci peralatan dapur terkait perekonomian yang dirasa berat saat Pandemi Covid-19.

\section{DAFTAR PUSTAKA}

Adhari, H., Yusnimar., \& Utami, S. P. (2016). Pemanfaatan minyak jelantah menjadi biodiesel dengan katalis $\mathrm{ZnO}$ presipitan zinc karbonat: pengaruh waktu reaksi dan jumlah katalis. Jom FTEKNIK, 3(2), 1-7.

BPS. (2019). Statistik Minyak Kelapa Sawit Indonesia. Jakarta: Indonesia. Retrieved February 10, 2020, from www.bps.go.id.

Erna, N. S., \& Wiwit, W. S. (2017). Pengolahan minyak goreng bekas (jelantah) sebagai pengganti bahan bakar minyak tanah (biofuel) bagi pedagang gorengan di sekitar FMIPA Unnes. Rekayasa, 15(2), 89-95.

Ernawati, D., \& Aryani, T. (2018). PKM pemberdayaan kelompok usaha Al Barik pengolahan tepung kulit pisang di Desa Sidomulyo Bambanglipuro Bantul. Dinamisia, 3(1),31-35.

Erviana, V. Y., Suwartini, I., \& Mudayana, A. A. (2018). Pengolahan minyak jelantah dan kulit pisang menjadi sabun. Solma, 7(2), 144-152.

Haqq, A. A. (2019). Pemanfaatan limbah minyak jelantah penghasil sabun sebagai stimulus untuk meningkatkan kepedulian masyarakat terhadap lingkungan. Dimasejati, 1(1), 119-136.

Harahap, J., \& Yulia. (2018). Potensi pemanfaatan limbah minyak jelantah kota Banda Aceh sebagai sumber energi alternatif (biodiesel). Elkawnie: Journal of Islamic Science and Technology, 4(2), 51-64.

Kusumaningtyas, R. D., Qudus, N., Putri, D. A., \& Kusumawardani, R. (2018). Penerapan teknologi pengolahan limbah minyak goreng bekas menjadi sabun cuci piring untuk pengendalian pencemaran dan pemberdayaan masyarakat. Abdimas, 22(2), 201-208.

Lipoeto, E. (2011). Synthesis of biodiesel via acid catalysis. Ind. Eng. Chem. Research, 44(14), 53535363.

Priyanto, A., Prayogi, D. S., Fitriya, N., Karunawan, J., Sulhadi., \& Aji, M. P. (2017). Pemanfaatan minyak jelantah sebagai fotokatalis carbon nanodots untuk penjernihan air limbah batik. Prosiding Seminar Nasional Fisika (E-Journal) SNF, 7, 2339-0654.

Rozaq, L., \& Laksanawati, W. D. (2018). Pemanfaatan limbah sisa minyak goreng dan serbuk kopi menjadi sabun wangi untuk keperluan rumah tangga dan alternatif industri skala rumah tangga sebagai konsep mandiri ekonomi bagi anggota koperasi wanita. Sembadha, 1(1), 247 250.

Suryani, L., Aje, A.U., \& Tute, J. (2019). PKM pelatihan kelompok anak cinta lingkungan Kabupaten Ende dalam pegelolaan limbah organik dan anorganik berbasis 3R untuk mengeskalasi nilai ekonomis barang sebagai bekal wirausaha mandiri. Dinamisia, 3(2), 244-251.

Syam, M., Putra, A. E. E., Amaliyah, N., \& Hayat, A. (2018). Peluang pemanfaatan limbah minyak goreng sebagai bahah baku biodiesel di Makassar. Tepat, 1(2), 155-161.

Syarifuddin, H., \& Hamzah. (2019). Prospek pemanfaatan limbah batang pisang dalam mendukung ekonomi kreatif masyarakat ramah lingkungan. Dinamisia, 3, 27-34. 